\title{
First Record of Greenland Halibut (Reinhardtius hippoglossoides) in the Beaufort Sea (Arctic Ocean)
}

\author{
D.B. CHIPERZAK, ${ }^{1}$ F. SAURETTE ${ }^{1}$ and P. RADDI ${ }^{2}$
}

(Received 4 January 1995; accepted in revised form 16 August 1995)

\begin{abstract}
Eleven Greenland halibut (Reinhardtius hippoglossoides) were captured in two longline sets in the offshore waters $\left(71^{\circ} 45^{\prime} \mathrm{N}, 127^{\circ} 08^{\prime} \mathrm{W}\right)$ of Sachs Harbour, Banks Island, Northwest Territories. This is the first record of Greenland halibut in the Beaufort Sea and Arctic Ocean. The Greenland halibut were captured in the Atlantic water layer of the Beaufort Sea at a depth of approximately $430 \mathrm{~m}$, with a temperature of $0.3^{\circ} \mathrm{C}$ and salinity of $34.8 \%$.
\end{abstract}

Key words: first record, Greenland halibut, Reinhardtius hippoglossoides, Atlantic water mass, Beaufort Sea, Arctic Ocean

RÉSUMÉ. On a capturé onze flétans du Groenland (Reinhardtius hippoglossoides) dans deux jeux de palangres placés dans les eaux au large ( $\operatorname{par} 71^{\circ} 45^{\prime}$ de latit. N. et $127^{\circ} 08^{\prime}$ de longit. O.) de Sachs Harbour, dans l'île Banks située dans les Territoires du NordOuest. C'est la première fois que l'on enregistre la présence du flétan du Groenland dans la mer de Beaufort et l'océan Arctique. Les flétans du Groenland ont été pris dans la couche d'eau de l'Atlantique de la mer de Beaufort à une profondeur d'environ 430 $\mathrm{m}$, avec une température de $0,3^{\circ} \mathrm{C}$ et une salinité de 34,8 p. mille.

Mots clés: premier relevé, flétan du Groenland, Reinhardtius hippoglossoides, masse d'eau de l'Atlantique, mer de Beaufort, océan Atlantique

Traduit pour la revue Arctic par Nésida Loyer.

Eleven Greenland halibut (Reinhardtius hippoglossoides) were captured from the offshore waters of Banks Island, Northwest Territories, during a winter exploratory groundfish survey. The objectives of the exploratory survey were to investigate the presence or absence of commercial groundfish species in the offshore waters of Banks Island during the iceon period, and to provide recommendations to the Inuvialuit Fisheries Joint Management Committee as to the potential for a winter fishery such as currently exists in Cumberland Sound (Crawford, 1992; Pike, 1994).

Greenland halibut, a deep water flatfish in the family Pleuronectidae, is commercially harvested in both the Atlantic and Pacific Oceans, under the name Greenland turbot. It is easily distinguished from other pleuronectids by the dark colour of its blind (left) side (Hart, 1973) and by its straight lateral line (Scott and Scott, 1988). In addition, its left eye is located on the dorsal margin of its head instead of having migrated fully to the right side as in other pleuronectids (Atkinson et al., 1982).

Greenland halibut has previously been described as having an amphiboreal distribution (Andriyashev, 1954; Hubbs and Wilimovsky, 1964; Atkinson et al., 1982; Alton et al., 1988; Crawford, 1992), being present in both the Atlantic and Pacific Oceans but unknown in the intervening Arctic Ocean. Hubbs and Wilimovsky (1964) suggested that this species may have occurred in the Arctic Ocean during the last interglacial or postglacial hypsithermal period, when Arctic waters were warmer.

Greenland halibut from the Pacific and Atlantic Oceans were considered to be two separate species (Andriashev, 1954), but Hubbs and Wilimovsky (1964) concluded on the basis of morphometric and meristic characteristics that they were one species. Later Fairbairn (1981), using biochemical genetic techniques, found genetic divergence at the subspecific level between Greenland halibut from the Northwest Atlantic and those from the Bering Sea.

In the Pacific Ocean, Greenland halibut is found universally from Japan north to the Chukchi Peninsula (Federov, 1971), with species abundance centered in the eastern Bering Sea and in the Aleutian Islands (Alton et al., 1988). In the western Pacific it occurs in the Okhotsk Sea (Andriyashev, 1954; Novikov, 1960; Shuntnov, 1965) but is rare in the Japan Sea (Novikov, 1960). Greenland halibut have been captured as far north as Norton Sound, Alaska (Alton et al., 1988), and occasionally as far south as off the coast of British Columbia (Westrheim and Pletcher, 1966), California (Best, 1963; Schott, 1966), and Baja California, Mexico (Hubbs and Wilimovsky, 1964).

In the Atlantic Ocean, Bowering and Chumakov (1989) report Greenland halibut as being continuously distributed from Davis Strait south to the northern slopes of the Newfoundland Grand Banks. They are found as far north as Smith

\footnotetext{
${ }^{1}$ Department of Fisheries and Oceans, 501 University Crescent, Winnipeg, Manitoba R3T 2N6, Canada

${ }^{2}$ Hunter and Trappers Committee, Sachs Harbour, Banks Island, Northwest Territories X0E 0X0, Canada

(C) Department of Fisheries and Oceans, Government of Canada
} 


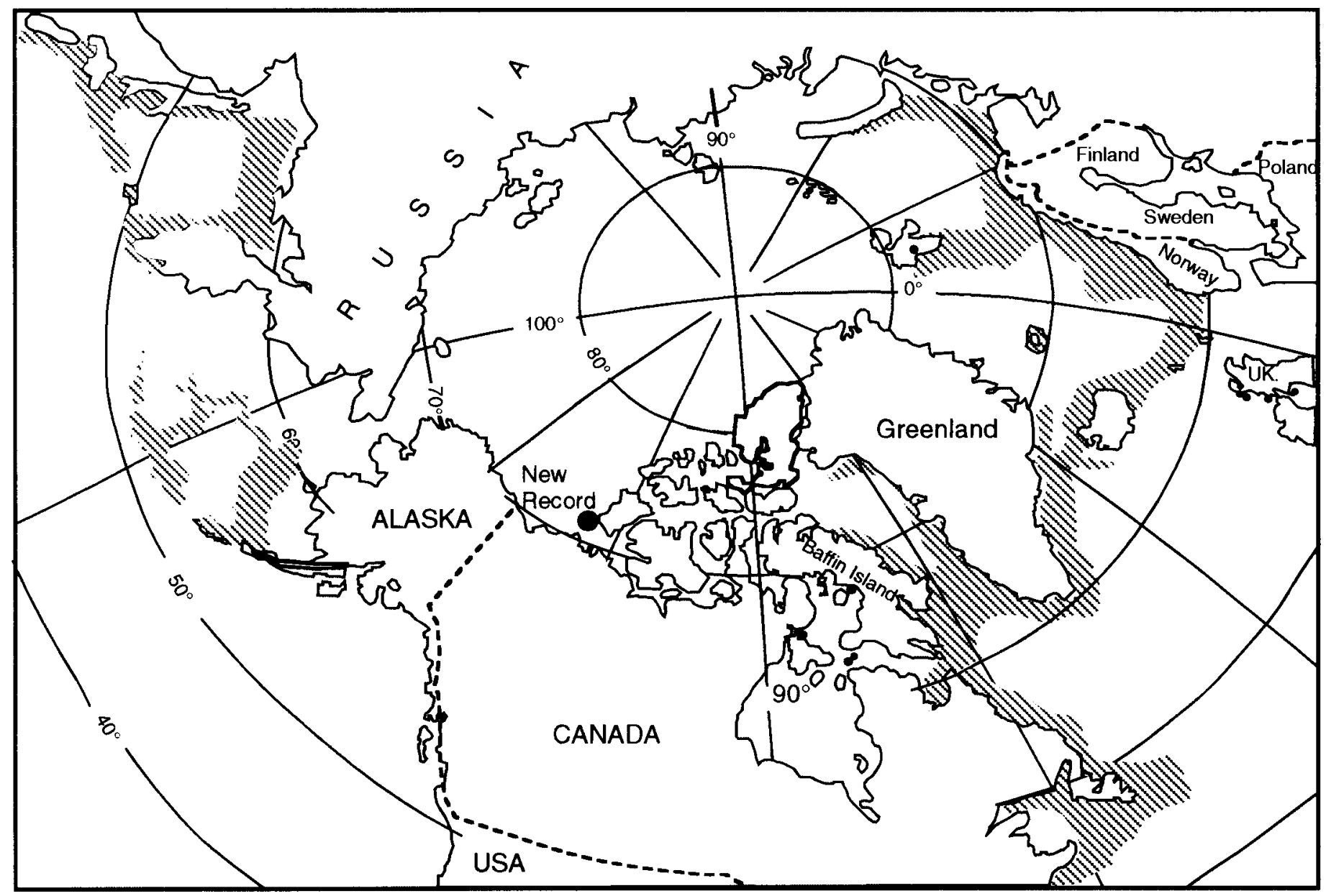

FIG. 1. Geographical distribution including new record of Greenland halibut, Reinhardtius hippoglossoides. (Modified from Alton et al., 1988.)

Sound (Templeman, 1973), are abundant during the winter months in Cumberland Sound, Baffin Island, Northwest Territories (Crawford, 1992), and are occasionally abundant in the fjords of east and west Greenland (Smidt, 1969). Additionally they are present in Hudson Strait and Ungava Bay (Dunbar and Hildebrand, 1952). Greenland halibut have been captured as far south as the Gulf of Maine during a period of low water temperatures (Boyar, 1964). They are widely distributed in the Gulf of St. Lawrence (Bowering, 1982) to the edge of the Scotian Shelf (Templeman, 1973), but are rare in the Bay of Fundy (Barrett, 1968). To the east they are captured off Iceland (Sigurdson, 1981) and in the eastern Norwegian and Barents Seas (Andriyashev, 1954).

In March 1993, two longline sets were made to a depth of approximately $430 \mathrm{~m}$ in the Beaufort Sea. The two sets were made through drifting pack ice, offshore of Sachs Harbour, Banks Island (Fig. 1). Each set consisted of 99 baited circle hooks fished along the bottom. Bottom substrate was mud, as evidenced by dirty baits and mud along the line itself. The first set was made on March 11 , at $71^{\circ} 45^{\prime} 54^{\prime \prime} \mathrm{N}$, $127^{\circ} 09^{\prime} 26.5^{\prime \prime} \mathrm{W}$ and retrieved on March 12 (after $17 \mathrm{hrs}$ and $45 \mathrm{~min}$ ) at $71^{\circ} 45^{\prime} 48^{\prime \prime} \mathrm{N}$ and $127^{\circ} 08^{\prime} 19^{\prime \prime} \mathrm{W}$. Eight Greenland halibut were captured. The line was rebaited, set, and retrieved 24 hours later (March 13) at $71^{\circ} 45^{\prime} 21.5^{\prime \prime} \mathrm{N}$ and $127^{\circ} 05^{\prime} 59^{\prime \prime} \mathrm{W}$. Three Greenland halibut were captured from this second set. Five of the Greenland halibut have been deposited with the Canadian Museum of Nature in Ottawa, Canada. Three fish from longline set one are catalogued under NMC 93-0117 and two fish from set two are catalogued under NMC 93-0118.

The station was reoccupied on March 15, having now drifted to $71^{\circ} 40^{\prime} 55.8^{\prime \prime} \mathrm{N}$ and $126^{\circ} 56^{\prime} 29.7^{\prime \prime} \mathrm{W}$, to obtain a conductivity, temperature and depth (CTD) profile. Temperature and depth were taken within two metres of the bottom. Salinity was $34.80 \%$, while temperature was $0.3^{\circ} \mathrm{C}$. These data suggest that this bottom layer of water is Atlantic in origin. The Atlantic water that enters the Arctic Ocean from the Greenland Sea (Coachman and Barnes, 1963; Aagaard and Coachman, 1977; Treshnikov, 1977) is characterized by salinities greater than $34 \%$ and temperatures greater than $0^{\circ} \mathrm{C}$ (Coachman, 1969; Melling and Lewis, 1982; Melling, 1983) and is found in depths greater than $250 \mathrm{~m}$ (Melling and Lewis, 1982; Melling, 1983) to depths exceeding $1000 \mathrm{~m}$ (Coachman, 1969).

The average total length of the Greenland halibut captured was $576 \mathrm{~mm}$, with a range of $450 \mathrm{~mm}$ to $815 \mathrm{~mm}$ (Table 1). Mean weight was $2166 \mathrm{~g}$, with a range of $831 \mathrm{~g}$ to $5762 \mathrm{~g}$. All of the Greenland halibut were female except for one immature male. One female was mature, suggesting that spawning occurs in the Beaufort Sea. The remaining females 
TABLE 1. Lengths, weights, sex, age, and meristic counts for Greenland halibut captured in the Beaufort Sea, March 1993.

\begin{tabular}{|c|c|c|c|c|c|c|c|c|c|c|c|}
\hline $\begin{array}{c}\text { Fish } \\
\text { Number }\end{array}$ & $\begin{array}{c}\text { Total } \\
\text { Length }(\mathrm{mm})\end{array}$ & $\begin{array}{c}\text { Stand } \\
\text { Length (mm) }\end{array}$ & $\begin{array}{l}\text { Weight } \\
\text { (g) }\end{array}$ & Dorsal Fin & Anal Fin & Right Pect & Left Pect & Right Pelv & Left Pelv & Sex & Age \\
\hline 37230 & 609 & 545 & 2407 & 95 & 72 & 13 & 14 & 6 & 6 & $\mathrm{~F}$ & 9 \\
\hline 37232 & 560 & 502 & 1745 & 101 & 74 & 13 & 13 & 6 & 6 & $\mathrm{~F}$ & 9 \\
\hline 37233 & 450 & 410 & 831 & 94 & 72 & 14 & 14 & 6 & 6 & $\mathrm{~F}$ & 9 \\
\hline 37234 & 502 & 446 & 1305 & 101 & 72 & 13 & 13 & 6 & 6 & F & 8 \\
\hline 37235 & 562 & 505 & 1970 & 95 & 71 & 14 & 14 & 6 & 6 & $\mathrm{~F}$ & 8 \\
\hline 37238 & 565 & 512 & 1902 & 103 & 75 & 14 & 15 & 6 & 6 & F & 9 \\
\hline 37239 & 572 & 531 & 2230 & 98 & 77 & 13 & 13 & 6 & 6 & F & $\mathrm{NA}^{1}$ \\
\hline 37240 & 815 & 734 & 5762 & 97 & 71 & 14 & 14 & 6 & 6 & F & 12 \\
\hline
\end{tabular}

${ }^{1} \mathrm{NA}=$ Not aged

were all immature. Ages read from the left saccular otolith were eight and nine years except for the mature female, which was age twelve.

Meristic counts for dorsal, anal, right and left pectoral and pelvic fins (Table 1) fall within the range found in Greenland halibut in both the Atlantic Ocean (Templeman, 1973) and Pacific Ocean (Hubbs and Wilimovsky, 1964).

These captures represent a significant westward range extension of approximately $2400 \mathrm{~km}$ from the Greenland halibut's nearest known capture locality in the eastern Canadian Arctic Archipelago (Cumberland Sound: Crawford, 1992; Pike, 1994) and an eastward extension from the Pacific Ocean (Norton Sound: Alton et al., 1988) of $1800 \mathrm{~km}$. Further study is required on Greenland halibut to determine its distribution and abundance within the Arctic Ocean and to determine the relationship between its Atlantic and Pacific subspecies.

\section{ACKNOWLEDGEMENTS}

Funding for this project was provided by the Department of Fisheries and Oceans/Inuvialuit Fisheries Joint Management Committee. We thank the Polar Continental Shelf Project for providing logistical support. The assistance of the Inuvik Research Laboratory is also gratefully acknowledged. Ageing was done by Margaret Keast. The loan of the CTD probe, software and helpful instructions by R. Pearson of the Institute of Ocean Sciences, Sidney, B.C. were much appreciated. Many thanks to the Sachs Harbour Hunters and Trappers' Committee for their support of this project. J. Reist and R. Tallman reviewed this paper and their comments and suggestions are greatly appreciated.

\section{REFERENCES}

AAGAARD, K., and COACHMAN, L.K. 1977. Recent studies on Arctic currents. In: Dunbar, M.J., ed. Polar oceans. Calgary: Arctic Institute of North America. 87-98.

ALTON, M.S., BAKKALA, R.G., WALTERS,G.E., and MUNTO, P.T. 1988. Greenland turbot Reinhardtius hippoglossoides of the Eastern Bering Sea and Aleutian Islands region. NOAA Technical Report, National Marine Fisheries Service, 71.31 p. ANDRIYASHEV, A.P. 1954. Ryby severnykh morsei SSSR. Opred Faune SSSr. 53:1-566. English translation, 1964. Fishes of the northern seas of the U.S.S.R. Jerusalem: Israel Program for Scientific Translations. $617 \mathrm{p}$.

ATKINSON, D.B., BOWERING, W.R., PARSONS, D.G., HORSTED, SV.AA., and MINET, J.P. 1982. A review of the biology and fisheries for roundnose grenadier, Greenland halibut, and northern shrimp in Davis Strait. North Atlantic Fisheries Organization Science Council Studies 3:7-27.

BARRETT, B.E. 1968. First occurrence of Greenland halibut (Reinhardtius hippoglossoides) in the Bay of Fundy. Journal of the Fisheries Research Board of Canada 25(12):2721-2722.

BEST, E.A. 1963. Greenland halibut, Reinhardtius hippoglossoides (Walbaum), added to California fauna. California Fish and Game 49(3):213-214.

BOWERING, W.R. 1982. Population dynamics of Greenland halibut in the Gulf of St. Lawrence. Journal of the Northwest Atlantic Fisheries Science 3:141-147.

BOWERING, W.R., and CHUMAKOV, A.K. 1989. Distribution and relative abundance of Greenland halibut Reinhardtius hippoglossoides (Walbaum) in the Canadian Northwest Atlantic from Davis Strait to the northern Grand Bank. Fisheries Research 7:301-327.

BOYAR, H.C. 1964. Occurrence of the Greenland halibut, Reinhardtius hippoglossoides (Walbaum), in shallow waters in the Gulf of Maine. Copeia 1964(1):232-233.

COACHMAN, L.K. 1969. Physical oceanography in the Arctic Ocean: 1968. Arctic 22(3):211-224.

COACHMAN, L.K., and BARNES, C.A. 1963. The movement of Atlantic water in the Arctic Ocean. Arctic 16:8-16.

CRAWFORD, R.E. 1992. Life history of the Davis Strait Greenland halibut, with reference to the Cumberland Sound fishery. Canadian Manuscript Report of Fisheries and Aquatic Sciences 2130. 19 p.

DUNBAR, M.J., and HILDEBRAND, H.H. 1952. Contribution to the study of the fishes of Ungava Bay. Journal of the Fisheries Research Board of Canada 9:83-128.

FAIRBAIRN, D.J. 1981. Biochemical genetic analysis of population differentiation in Greenland halibut (Reinhardtius 
hippoglossoides) from the Northwest Atlantic, Gulf of St. Lawrence, and Bering Sea. Canadian Journal of Fisheries and Aquatic Science 38:669-677.

FEDEROV, K.YE. 1971. Zoogeographic characteristics of Greenland halibut, Reinhardtius hippoglossoides (Walbaum). Voprosy Ikhtiologii [Journal of Ichthyology] 11(6):971-975.

HART, J.L. 1973. Pacific fishes of Canada. Bulletin of the Fisheries Research Board of Canada No. 180. 740 p.

HUBBS, C.L., and WILIMOVSKY, N.J. 1964. Distribution and synonymy in the Pacific Ocean and variation of the Greenland halibut, Reinhardtius hippoglossoides (Walbaum). Journal of the Fisheries Research Board of Canada 21:1129-1154.

MELLING, H. 1983. Oceanic features of the Beaufort Sea in early winter. Canadian Technical Report of Hydrography and Ocean Sciences No. 20. 42 p.

MELLING, H., and LEWIS, E.L. 1982. Shelf drainage flows in the Beaufort Sea and their effect on the Arctic Ocean pycnocline. Deep-Sea Research 29(8A):967-985.

NOVIKOV, N.P. 1960. Bering Sea halibuts. Paltusy Beringova moria. Rybnoe Khoziaistvo 36(1):12-15. Translation No. 9 of the International North Pacific Fisheries Commission. Ottawa: Fisheries Research Board of Canada Translation Series No. 329.

PIKE, D.G. 1994. The fishery for Greenland halibut (Reinhardtius hippoglossoides) in Cumberland Sound, Baffin Island, 1987 1992. Canadian Technical Report of Fisheries and Aquatic Sciences No. 1924. 20 p.

SCHOTT, J.W. 1966. A Greenland halibut, Reinhardtius hippoglossoides (Walbaum) recorded in southern California. California Fish and Game 52(1):55-56.
SCOTT, W.B., and SCOTT, M.G. 1988. Atlantic fishes of Canada. Canadian Bulletin of Fisheries and Aquatic Sciences 219.731 p.

SHUNTNOV, V.P. 1965. Distribution of the Greenland halibut and arrowtooth halibuts in the north Pacific. Vsesoyuznyi NauchnoIssledovatel'skii Institut Morskogo Rybnogo Khozyaistva I Okeanografii 53:155 - 163. English translation, 1968. In: Soviet fisheries investigation in the northeastern Pacific, Part IV. 147156. Jerusaleum: Israel Program for Scientific Translations.

SIGURDSON, A. 1981. Migrations of Greenland halibut Reinhardtius hippoglossoides (Walb.) from Iceland to Norway. Rit Fiskideildar 6(1):3-6.

SMIDT, E.L.B. 1969. The Greenland halibut (Reinhardtius hippoglossoides, Walbaum), biology and exploitation in Greenland waters. Meddelelser Fra Danmarks Fiskeri og Havundersøgelser 6:79-118.

TEMPLEMAN, W. 1973. Distribution and abundance of the Greenland halibut, Reinhardtius hippoglossoides (Walbaum), in the Northwest Atlantic. International Commission for the Northwest Atlantic Fisheries Research Bulletin 10:82-98.

TRESHNIKOV, A.F. 1977. Water masses of the Arctic Basin. In: Dunbar, M.J., ed. Polar oceans. Calgary: Arctic Institute of North America. 17-31.

WESTRHEIM, S.J., and PLETCHER, F.T. 1966. First records of the twoline eelpout, Bothrocara brunneum, Greenland halibut, Reinhardtius hippoglossoides, and shortbelly rockfish, Sebastodes jordani, in British Columbia waters. Journal of the Fisheries Research Board of Canada 23(2):309-312. 